\title{
Wood Decay Hazard in Canada Based on Scheffer's Climate Index Formula
}

\author{
by
}

\author{
E.C. Setliff ${ }^{1}$
}

\begin{abstract}
Scheffer's formula for determining the overall decay hazard in above ground wooden structures was applied to Canada. For the most heavily populated areas of southwestern British Columbia, southern Ontario, southern Quebec and the Maritimes, the decay hazard fell into Scheffer's revised intermediate decay hazard range of 35 to 70 . Based on the weather station data used, Cape Scott at the northern end of Vancouver Island, had the highest decay hazard level of 79.7. This contrasted with a decay index of 0.6 at Alert, NWT at $82^{\circ} \mathrm{N}$ latitude.
\end{abstract}

Keywords: Decay, decay hazard, wooden structures, wood preservation, wood deterioration, meteorology, Canada.

\section{Résumé}

La formule de Scheffer pour déterminer le risque absolu de pourriture sur les structure de bois édifiées au dessous du sol, a été appliquée au Canada. Pour les zones les plus densément peuplées du sud-ouest de la Colombie Britannique, le sud de l'Ontario, le sud du Québec et les Maritimes, la valeur de l'indice de risque de pourriture selon l'échelle revisée de risque intermédiaire de Scheffer, se situe entre 35 et 70 . Selon la station météorologique utilisée, Cape Scott, à l'extrémité nord de l'lle de Vancouver, a obtenu le niveau le plus élevé de risque de pourriture avec une valeur de 79.7. Ceci contraste avec la valeur de risque de 0.6 à Alert, T.N.O., le long du $82^{\circ}$ de latitude nord.

Mots clés : Pourriture, risque de pourriture, structure de bois, préservation du bois, deterioration du bois, météorologie, Canada.

\section{Introduction}

In assessing wood decay problems in North America, it is important that biologists and wood preservers have an overall understanding of the decay potential. Also, as the public's environmental awareness develops simultaneously with decreasing resources, the need to maintain a balanced perspective on resource utilization and conservation becomes increasingly important. As suggested earlier (Scheffer 1971), preservative treatments of wood must relate to climate in some objective manner, and to a large extent this depends on temperature and rainfall as two important factors in the decay process. Most fungi that decay wood do so more rapidly at higher average temperatures and relative humidities. On this basis, Scheffer established a "climate index" formula for decay hazard in above ground structures in the United States. This formula has now been used to establish the decay indexes for Canada. The word combination "decay index" is used in this paper instead of "climate index".

\section{Methods}

The decay index calculations were based on Scheffer's formula

1Lakehead University, School of Forestry, Thunder Bay, Ont. P7B 5E1.

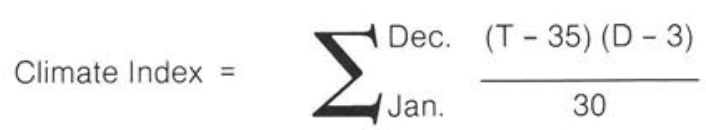

where $\mathrm{T}$ is the mean monthly temperature $\left({ }^{\circ} \mathrm{F}\right) ; \mathrm{D}$ is the mean number of days in the month with 0.01 inch or more precipitation; and

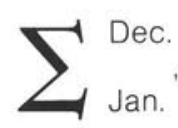

is the summation of products for the respective months, January through December. The climatological data on temperature and precipitation were derived from Canadian Climate Normals (Environ. Can. 1982). Weather station data were selected that represented large population centres and separate geographical areas.

Based on the decay index values, three decay hazard zones were established as follows: low hazard $<35$, intermediate 35-65, and high hazard $>65$ (Scheffer 1971). Later studies, based on the actual decay in houses, suggested that the upper limit of the intermediate decay range be increased to 70 (DeGroot and Esenther 1982); however this change is of little consequence in Canada. 


\section{Results and Discussion}

The decay indexes for each provincial site are given in Table I and the decay hazard zones are shown in Figure 1. The coastal regions of British Columbia have the highest rainfall and most moderate temperatures. Consequently, the northern tip of Vancouver Island, Cape Scott, has the highest rating of 79.7 and thereby ranks in the highest decay hazard level $(>70)$. The Queen Charlotte Islands just south of the Alaskan Panhandle have, with one exception, intermediate decay hazard ratings: 55.9 at Masset and 58.0 at Sandspit. The exception, the island of Langara just north of Graham Island, has a rating of 71 . The most heavily populated regions in southwest British Columbia have ratings that vary from 45.6 at the Vancouver International Airport, to 52.3 at the Vancouver Harbor. Victoria, at the southern end of Vancouver Island, is rated at 40.9. The climatic diversity of British Columbia is further reflected in low ratings of 14.4 at Atlin and 19.7 at Lytton.
The Prairie Provinces of Alberta, Saskatchewan, and Manitoba have decay indexes from a low of 23.5 at Lac la Biche, Alberta, to a high of 34.9 at Winnipeg, Manitoba, and are in the lowest decay hazard category $(<35)$.

Ontario, Quebec and the Maritime provinces have largely an intermediate level of decay hazard in the heavily populated areas. Of those weather stations considered, Chicoutimi, Quebec, has the highest rating at 52.2. Of interest were the ratings of 27.0 in Grand Falls, N.B., and 42.6 in Fredericton, N.B., only 150 kilometres apart.

The northern decay indexes for the Yukon and Northwest Territories were substantially lower than those of the rest of Canada. These values seem to realistically reflect both the cold temperatures and the low decay activity one might expect at these latitudes.

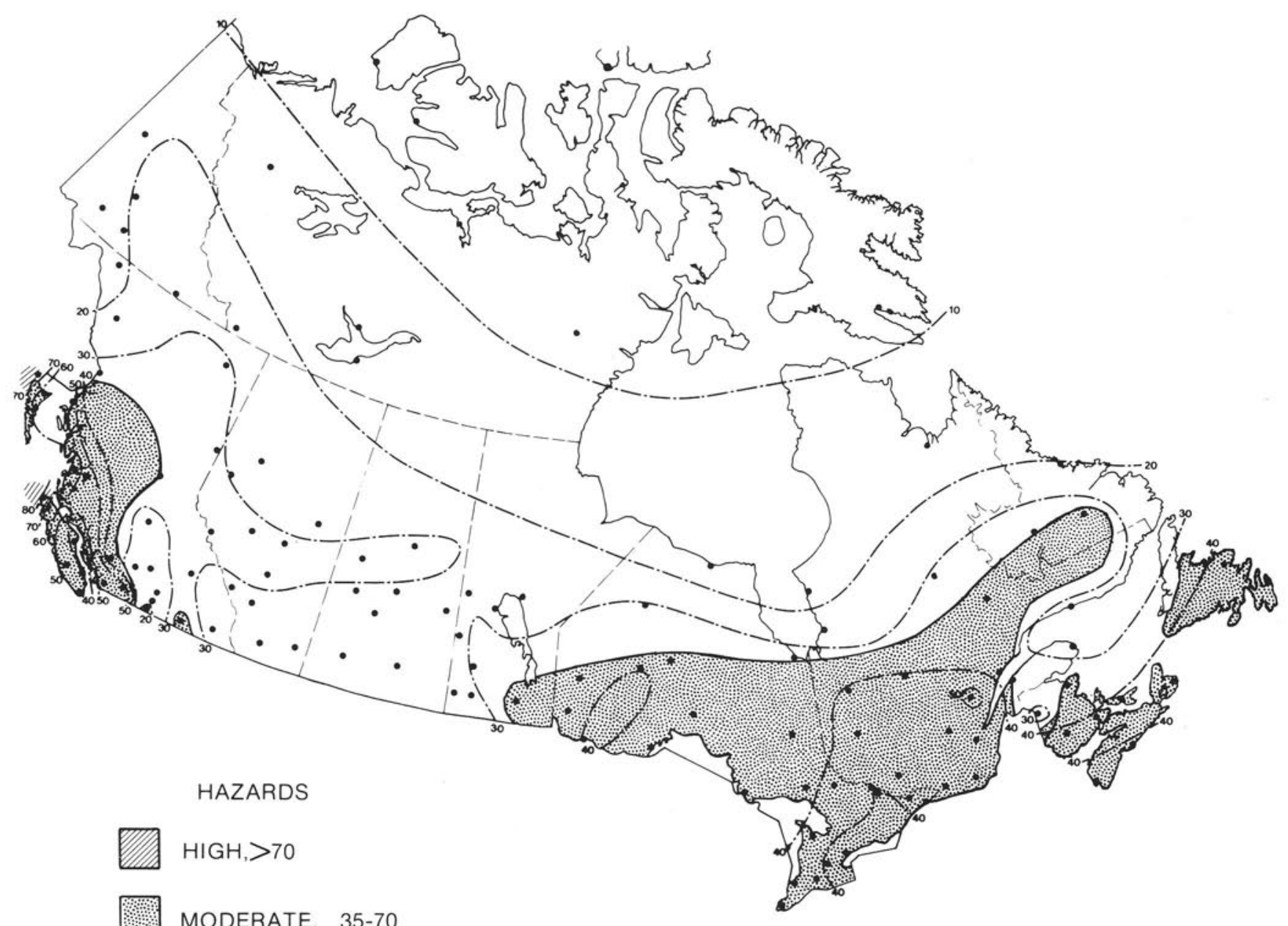

Figure 1. Decay hazard zones for above ground wooden structures in Canada. 
Table 1. Decay hazard indexes for above ground wooden structures in Canada.

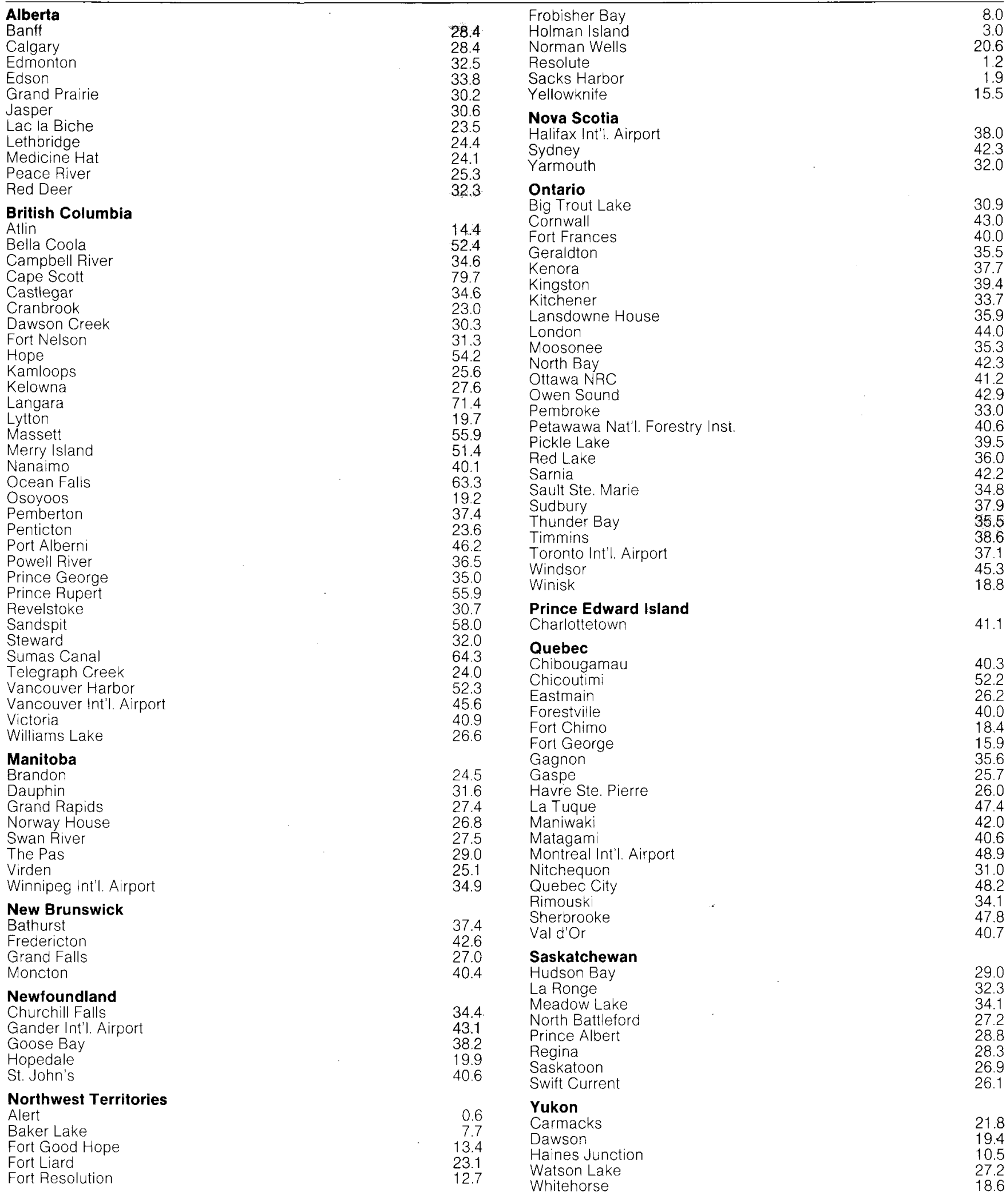


The decay hazard of wooden structures in Canada has been investigated less thoroughly than in the United States both from a theoretical and an experimental standpoint. To some extent this may be because of Canada's more northern geographic location and the perception of a low decay hazard. Also, in the past, there has been less concern about using the abundant "expendable" forest resource. However, with the ever-increasing cost of replacing bridges, storage tanks, and other exposed wooden structures, the awareness of the need for wood protection is becoming more acute. Of course, proper construction mostly eliminates decay problems in buildings.

The West Coast of British Columbia has the highest decay index figures, particularly northern Vancouver Island and the surrounding areas. However, the most heavily populated areas of British Columbia are rated at the intermediate decay hazard level. For Canada as a whole, Ontario, Quebec and the Maritimes probably face the heaviest potential monetary losses due to decay in wooden structures, again because of building and population densities.

Because rainfall and temperature are two important components in establishing the Fire Weather Index Zones in Canada (Simard 1973, Van Wagner 1974), further research in establishing the relationships of the two indexes based on this extensive meteorological information would be of interest.

In terms of eventually establishing standards for providing decay protection in wood frame construction, the kind and extent of treatment required depends on being able to quantify in some manner the decay hazards for different climatic areas. The decay index is an attempt to provide this kind of information. Field experiments are needed in Canada to better establish the accuracy of the decay index.

\section{Acknowledgements}

I should like to thank Eric, Alissa, and Dorene Setliff and A. Byrne for technical assistance. The critical reviews of the manuscript by $C$. Benson, K. Yang, and T. Eiber are gratefully acknowledged. This work was initiated at Forintek Canada Corp., Vancouver, B.C.

\section{References}

DeGroot, R.C. and G.R. Esenther. 1982. Microbial and entomological stresses on the structural use of wood. In Structural Use of Wood in Adverse Environments. R.W. Meyer and R.M. Kellogg, (eds.) Van Nostrand Reinhold Co., New York. p. 219245

Environment Canada. 1982. Canadian climate normals, 1951-1980, Vol. 2, temperature. Atmos. Environ. Serv. 306 p

Environment Canada. 1982. Canadian climate normals, 1951-1980, Vol. 3, precipitation. Atmos. Environ. Serv. 602 p.

Rowe, J.S. 1972. Forest regions of Canada. Can. For. Serv. Publ 1300. 172 p.

Scheffer, T.C. 1971. A climate index for estimating potential for decay in wood structures above ground. Forest Prod. J. 21:2531

Simard, A.J. 1973. Fire weather zones of Canada. Can. For. Serv map.

Van Wagner, C.E. 1974. Structure of the Canadian forest fire weather index. Can. For. Serv., Petawawa For. Exp. Stn. Publ. No. 1333. $43 \mathrm{p}$.
Change of Address

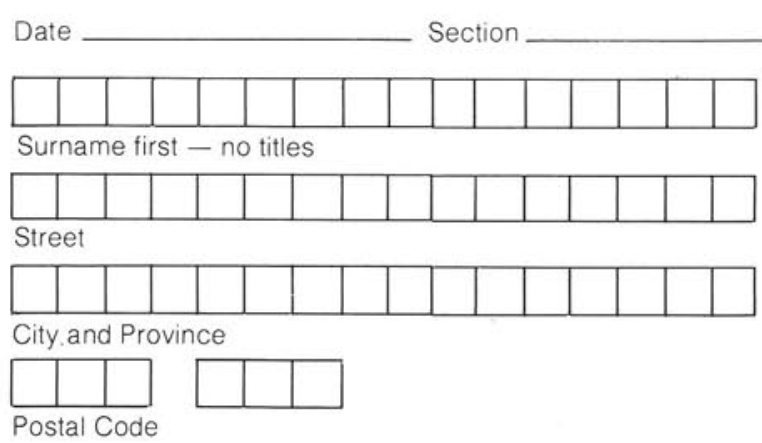

\section{Changement d'adresse}

Date Section

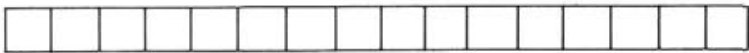

Prénom en avant - pas de titres
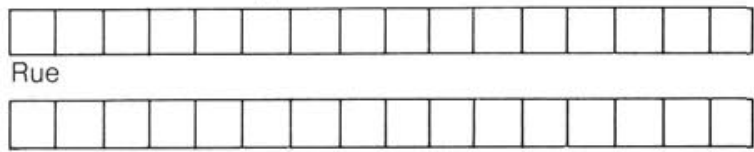

Ville et Province

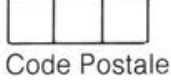

